JEASP

Journal of English for Academic and Specific Purposes

Volume 2 Number 1, June, 2019

\title{
THE STUDENT'S ABILITY TO WRITE A GOOD PARAGRAPH THROUGH DISCUSSION AT THE SECOND YEAR STUDENTS OF SMAN 1 PAKEL TULUNGAGUNG
}

\author{
Suparmo \\ (suparmosmansapa@gmail.com)
}

SMAN 1 Pakel Tulungagung

ARTICLE
Keywords:
As members of society, we are necessarily trained in writing activities, at
least in creating sentences to good paragraphs. However, there are reasons
how to read is not enough, and we are also interested in how to write
sentences very well (Zamel, 1987: 257). Writing a good paragraph is a
ability, a good
pamplex process that has been done and not easy for everyone. From four
language skills, writing a composition is considered as a subject that is
difficult to master. Mastery of writing is not a skill which can be learned in
isolation. It means that writing is integrated by the other language skills
such as reading, speaking, and listening, (Richard \& Rodger (1999:56). The
usage of acceptable technique is essential in teaching-learning process
because it motivates the students to learn English. Therefore, the writer
provides a research question on whether the students have created their
composition easily through a peer-to-peer discussion. In this case, the
writer needs to observe whether there are different results of composing a
paragraph through a peer-to-peer discussion compared with the other
groups. The objectives of the study are whether students using the
discussion to write a good paragraph gain better scores in English than
those who do not. The writer collects the data from the students of the
second year. They were asked to write a paragraph based on specific topics
provided by a classroom teacher and choose three alternative topics to
write quickly. The first process was that the students were trained to write
a paragraph in a group. Next, in the final activity, they create a
composition. The result of research about making composition through a
discussion way is right. They can share each other to correct the mistakes.
With the result of the discussion, the students can create the composition
better the next day. The research concludes that making composition
through a discussion way is one of the solutions to make composition
easier for the students. Based on the result of research, the students enjoy writing a
paragraph through discussion way.




\section{INTRODUCTION}

According to Victoria Fromklin and Robert Rodmon (1978: 141), the development of writing was one of the great human inventions. It is difficult for many people to imagine language without writing; the spoken word seems intricately tied to the written word.

We have also recognized the form of language as oral language and written language. Oral language is used to express our ideas spontaneously, so the other people understand what we tell directly. While a written language is to express our ideas in writing form, it shows a train of thoughts to provide a piece of clear information on a written form, for example, in making a composition. The writing of a composition is a task which involves the writer in manipulating words in grammatically correct sentences. Then the sentences are linked to form a piece of continuous writing in which the writer can express his ideas and thoughts about a particular topic. The difficulty in writing is caused by some factors: psychological, linguistics, and cognitive.

In expressing our ideas through a composition, we should notice the other of importance, the order of the most common to the most critical problem (Gerald Levin, 1976: 44). Besides that, we may not forget about the using transition signals and a good paragraph structure because they are also crucial in making a composition.

Those two aspects language and rhetoric are equally crucial in composition, and hence both should be adequately used in an effective composition. The rhetorical aspect involves the organization of the sentences in a paragraph and of paragraphs in a complete composition. In other words, rhetoric refers to all techniques used to organize sentences into a paragraph or composition. From the explanation above, we can conclude that the organization is one of the essential factors in making a composition. Several things might keep the reader from proceeding continuously and smoothly, and one is the overall organization and development (Elizabeth Cowan, 1983: 119)..

According to Cynthia Ozick (1986: 48) a well-organized paragraph is one in which the sequence of sentences is logical and orderly. The other opinion states that organization of paragraph: the arranging of the sentences into the paragraph, the paragraph into the others by using transition signals and the application of a good paragraph structure.

\section{SOMETHING NEEDED IN WRITING COMPOSITION}

\section{Organization Through Transition Signal}

There is one final thing we need to check before we can be sure our writing is moving smoothly and continuously for the reader. We need to see if we have all along given the reader signals 


\section{JEASP}

Journal of English for Academic and Specific Purposes

Volume 2 Number 1, June, 2019

that indicate our direction (transition)and reminder signs that help the reader remember what we are writing about (Elizabeth Cowan, 1983: 145).

There are some of the more common types of transition signal and phrases useful for establishing strong links not only within paragraphs but also between paragraphs. Cynthia Ozick states that transition words and expressions create coherence by moving to a paragraph from one sentence to another more natural to follow.

According to James M. Mc. Crimon (1941: 129), occasionally a whole short paragraph may serve as a transition. Such a paragraph always comes to appoint where the author has finished one central unit of his composition and is about to start another. The transition paragraph may be used in several ways. It may sum up what has been said before beginning the next unit. It may introduce one or more illustrations of a point already made. Alternatively, it may state what the writer intends to do next.

\section{Organization Through Logical Order}

According to Cynthia Ozick (1986: 49), there are two ways to see the organization through logical order: chronological order (time order, the order in which we say events took place in the real word) and order of importance (an order of either decreasing or increasing importance).

Gerald Levin (1983; 44) states: In descriptive writing, the order of ideas may be spatial moving from background to foreground, from sky to earth, from north to south. In the exposition, if we are giving reasons for supporting a political candidate, we can state them in the order of importance, or we can move from specific actions (the candidate's voting record) to general attitudes and philosophy.

The principle of order usually will depend on the needs of clear exposition and the reader's knowledge of the subject. For example, in describing the care of an automobile, we would probably discuss simple procedures before complex ones - especially if our readers are new - car owners. In training mechanic in the repair of new engines, we might proceed from the most significant problems that mechanics are likely to encounter. 
JEASP

Journal of English for Academic and Specific Purposes

Volume 2 Number 1, June, 2019

\section{Organization Through Structures}

An ideal paragraph has three major structural parts: a topic sentence, supporting sentences, and a concluding sentence. It is better for us to use three parts above in making a composition so that the readers understand our writing easily.

\section{A topic sentence}

According to Cynthia Ozick (1986: 33), a topic sentence states the main idea of a paragraph and points the direction on for the other sentences to follow:

A topic sentence is often a useful summary or generalization that clarifies the main idea of each paragraph for the reader.

According to Oshima and Hogue (1983: 6), every good paragraph has a topic sentence, which clearly states the topic and the controlling idea of the paragraph. It is usually (but not always) the first sentence in the paragraph. A topic sentence is the most crucial sentence in a paragraph. It briefly indicates what the paragraph is going to discuss. For this reason, the topic sentence is a helpful guide to both the writer and the madder. The writer can see what information to include (and what information to exclude).

A good topic sentence stated by Oshima and Hogue as follows: is a complete sentence with a subject, a verb and generally a complement; states both the topic and the controlling idea of the paragraph; is neither too general nor too specific. It states the main idea clearly, but it does not give the specific details and is usually (but not always) in the first sentence in the paragraph.

\section{Supporting sentence}

To present only the topic sentence in a paragraph is not enough. Further information about the controlling idea in the topic sentence must be presented as well. Therefore, supporting sentences are needed. Supporting sentences are sentences written to contribute the main sentences in a paragraph. They can be in the form of examples, enumeration of details comparison of contrast, reasons arguments.

Supporting sentences, usually in a long and complex paragraph, can be divided into two parts, namely primary and secondary supporting sentences (Fleming and Glatthorn, 1965). 
JEASP

Journal of English for Academic and Specific Purposes

Volume 2 Number 1, June, 2019

According to Cynthia Ozick, whether written language is formed to inform, persuade, narrate, or entertain, a single topic sentence can barely stand on its own. A good topic sentence excited the readers' interest, developing that sentence into a full paragraph should satisfy that interest.

\section{The Concluding Sentence}

The concluding sentence is the last element of a paragraph. A concluding sentence is not necessary, but is very often helpful to the reader, because it signals the end of the paragraph and because it reminds him or her of the essential points.

A concluding sentence serves three purposes, they are: (1) It signals the end of the paragraph by using: In conclusion, In summary, finally; (2) It summarizes the main points of the paragraph; (3) It gives final comments on your topic and leaves the reader with the most important ideas to think about.

In the research, the writer uses unique technique considered to give a significant contribution by using "peer-to-peer discussion way" in the process of giving the material about how to make a good composition through three ways mentioned above (the bold statements). After that, the students are trained to write a composition in a group through a discussion way. In the situation, the students can share each other. The student finding the difficulties in finishing the composition, he/she can ask the smart student in the group. It is hoped the astute student helps to find a suitable solution in writing the composition. After it is trained by using the technique (through discussion way), next, the students are asked to create a composition individually in a test form.

\section{METHOD}

This research was in the class action research which was held in one and half month in the use of two cycles, cycle I and cycle II, which focuses on basic competence of Writing, expressing the ideas through written tasks. Before applying two cycles, the writer directly takes the result of the previous writing test. The aim is to compare the students' capability in writing the composition by using the ordinary way with the research technique (writing composition by using discussion way). The class action research was held in two cycles to know the accurate result.

The teacher gives examples of how to write an excellent composition based on three ways as follows: (1). Analyzing the usage of transition signal in making their composition, (2). Analyzing the usage of logical order, especially chronological order (CO) and Order of Importance (IO), (3) and 


\section{JEASP}

Journal of English for Academic and Specific Purposes

Volume 2 Number 1, June, 2019

analyzing the usage of a paragraph structure, especially about the topic sentence, supporting sentence and concluding sentence before giving writing assignments.

Based on the result of the first cycle the writer gives additional step to handle the drawback of the previous result by using the great division of the member of the group: in each group must have the right, excellent leader to help the students finding the difficulties in creating the composition based on three ways mentioned above.

In this stage, the writer also gives a questionnaire to know the students' idea about the method, "a peer-to-peer discussion" whether it is liked by the students and helps them to finish the writing assignments. This questionnaire will show the students' interest in finishing writing assignment through discussion way.

The subjects of the research are the third year students of SMAN 1 Pakel, especially XI IPA 2. They have learned some English materials, such as listening, reading, structure, and vocabulary in a longer time than the lower level. Moreover, the writer also considerers that their English experiences give a significant contribution to finish the writing assignment so they will be able to do the assignment fluently. By mastering the materials and having the English experiences, it is hoped that they can write a good paragraph to represent a sample in the research to make a good paragraph through discussion way.

The instrument used in this research is a free composition test. It was chosen as the instrument because in a free composition the students can produce their sentences and arrange them freely. In the test, the students are asked to write an essay consisting of $500-800$ words within minutes or one period of the learning time.

\begin{tabular}{|c|l|}
\hline The assignment of Cycle I & The assignment of Cycle II \\
\hline 1. How to improve our reading habit & 1. The characteristic of a good student \\
\hline 2. How to study English & 2. The flag ceremony is essential for student \\
\hline
\end{tabular}

Note

The topics are finished by the students in a group consisting of three students or through discussion. In this case, the students still have to finish the assignment individually, but if finding some troubles, they can discuss each other (in a group). 


\section{JEASP}

Journal of English for Academic and Specific Purposes

Volume 2 Number 1, June, 2019

There were three ways in seeing the organization of the paragraph, by using transition signals, arranging the sentences in a logical order, and applying a good paragraph structure. Besides, the writer wants to know the result of the paragraphs done by the students based on the following formula:

The formula of writing test

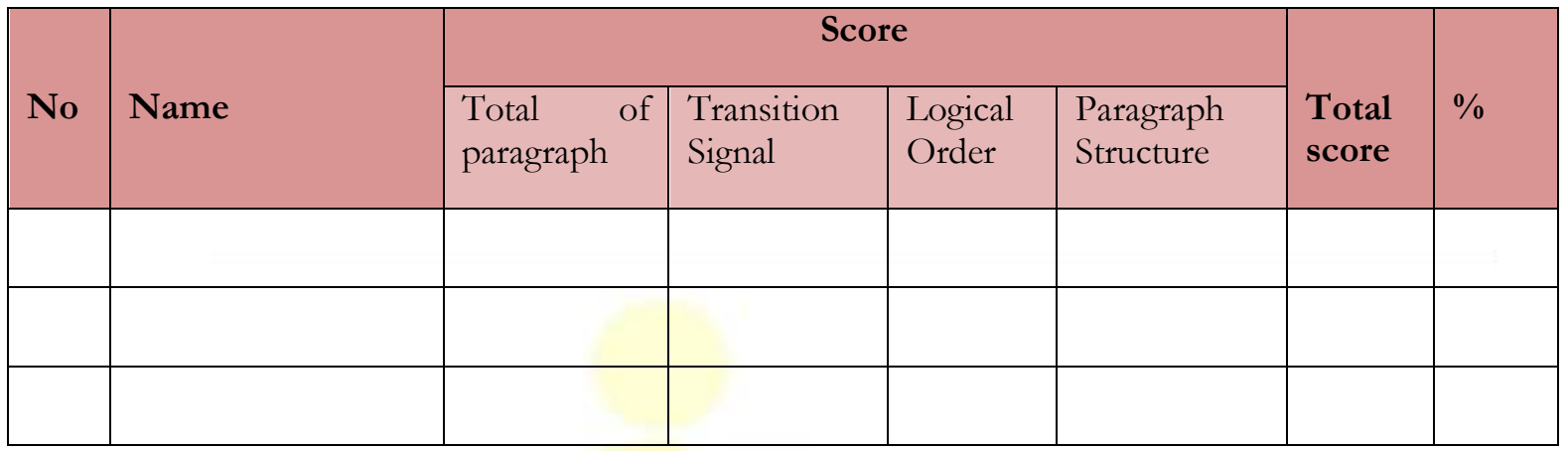

Score of result of writing test based on three categories:
$4=$ very good
$2=$ fair
$3=\operatorname{good}$
$1=\mathrm{bad}$

The information on the table above

\section{Score $=$ total score $\quad x \quad 100 \%$}

Note

The score is obtained from the total score of score from the transitional signal, logical order and paragraph structure usages then divided twelve (maximum score of each usage) the result of it times one hundred percent.

To know the students' interest in the discussion to a finish writing assignment, the writer distributed the questionnaire. If many students liked this way, it meant that the discussion way made the students more comfortable to finish writing assignments. Besides that, it can motivate the students to write a composition better. Here is the questionnaire form. 
JEASP

Journal of English for Academic and Specific Purposes

Volume 2 Number 1, June, 2019

\begin{tabular}{|l|l|l|l|}
\hline \multirow{2}{*}{ No } & \multirow{2}{*}{ Name } & \multicolumn{2}{|c|}{ Finishing writing assignment } \\
\cline { 3 - 4 } & & individual & Group \\
\hline & & & \\
\hline & & & \\
\hline & & & \\
\hline
\end{tabular}

\section{FINDINGS AND DISCUSSION}

\section{FINDINGS}

The writer held the test twice related to writing, making a composition. The tests were done by the students individually. However, before doing the tests, the students were trained to finish writing assignments in a group or through a discussion way. The writer observed the way the students in finishing the writing assignments through discussion way. Therefore, it is found that the students' interest in the peer-to-peer discussion was through a questionnaire. The result of the questionnaire was rolled out on the next page.

The Result of Writing Test before Research (Pre-test)

The criteria for minimal graduation $=75$

Mean: 72

table 1

The result of writing test of the cycle I

\begin{tabular}{|c|c|c|c|c|c|c|c|}
\hline \multirow[b]{2}{*}{ No } & \multirow[b]{2}{*}{ Name } & \multicolumn{4}{|c|}{ Score } & \multirow[b]{2}{*}{$\begin{array}{l}\text { Total } \\
\text { score }\end{array}$} & \multirow[b]{2}{*}{$\%$} \\
\hline & & $\begin{array}{l}\text { Total of } \\
\text { paragraph }\end{array}$ & $\begin{array}{l}\text { Transition } \\
\text { Signal }\end{array}$ & $\begin{array}{l}\text { Logical } \\
\text { Order }\end{array}$ & $\begin{array}{l}\text { Paragraph } \\
\text { Structure }\end{array}$ & & \\
\hline 1. & Agus S. & 3 & 3 & 3 & 3 & 9 & $75 \%$ \\
\hline 2. & Ratna & 3 & 3 & 3 & 3 & 9 & $75 \%$ \\
\hline 3. & Ardho Orani & 3 & 3 & 4 & 3 & 10 & $83 \%$ \\
\hline
\end{tabular}


JEASP

-2Sla Journal of English for Academic and Specific Purposes

Volume 2 Number 1, June, 2019

\begin{tabular}{|c|c|c|c|c|c|c|c|}
\hline 4. & Rizki Nur A. & 3 & 3 & 4 & 4 & 11 & $91 \%$ \\
\hline 5. & Sulis Setiyo & 3 & 4 & 4 & 3 & 11 & $91 \%$ \\
\hline 6. & Andini Erdian & 3 & 3 & 3 & 3 & 9 & $75 \%$ \\
\hline 7. & Ainin S & 3 & 3 & 4 & 3 & 10 & $83 \%$ \\
\hline 8. & Denddy Purwo & 3 & 3 & 2 & 2 & 7 & $58 \%$ \\
\hline 9. & Dhimas Adi & 3 & 3 & 3 & 2 & 8 & $66 \%$ \\
\hline 10. & Frita Ferdina & 3 & 3 & 3 & 3 & 9 & $75 \%$ \\
\hline 11. & Desi Yunita & 3 & 3 & 3 & 2 & 8 & $66 \%$ \\
\hline 12. & Destanto & 3 & 2 & 4 & 3 & 9 & $75 \%$ \\
\hline 13. & Linda Yunita & 3 & 3 & 3 & 3 & 9 & $75 \%$ \\
\hline 14. & Septi Peria Sari & 3 & 3 & 2 & 3 & 8 & $66 \%$ \\
\hline 15. & Yuda Tri & 3 & 2 & 4 & 4 & 10 & $83 \%$ \\
\hline 16. & Alfa Rindarini & 3 & 3 & 3 & 2 & 8 & $66 \%$ \\
\hline 17. & Arinta Novia & 3 & 3 & 3 & 2 & 8 & $66 \%$ \\
\hline 18. & Denis Kholida & 3 & 3 & 3 & 3 & 9 & $75 \%$ \\
\hline 19. & Ersi Egi & 3 & 3 & 3 & 3 & 9 & $75 \%$ \\
\hline 20. & Fitriana April & 3 & 3 & 4 & 3 & 10 & $83 \%$ \\
\hline 21. & Ihsan W. & 3 & 3 & 4 & 4 & 11 & $91 \%$ \\
\hline 22. & Nugroho Eko & 3 & 4 & 4 & 3 & 11 & $91 \%$ \\
\hline 23. & Eko Sukma & 3 & 3 & 3 & 3 & 9 & $75 \%$ \\
\hline 24. & Umi Saadah & 3 & 3 & 4 & 3 & 10 & $83 \%$ \\
\hline 25. & Uvike Zuria & 3 & 3 & 2 & 2 & 7 & $58 \%$ \\
\hline 26. & Yoesiva A. & 3 & 3 & 3 & 2 & 8 & $66 \%$ \\
\hline 27. & Arif Fandi & 3 & 3 & 3 & 3 & 9 & $75 \%$ \\
\hline 28. & Imam Supono. & 3 & 3 & 3 & 2 & 8 & $66 \%$ \\
\hline 29. & Priyo Emran. & 3 & 3 & 3 & 3 & 9 & $75 \%$ \\
\hline 30. & Anisa Santana & 3 & 3 & 3 & 3 & 9 & $75 \%$ \\
\hline
\end{tabular}


JEASP

as Journal of English for Academic and Specific Purposes

Volume 2 Number 1, June, 2019

\begin{tabular}{|c|c|c|c|c|c|c|c|}
\hline 31. & Bagus Nandar & 3 & 3 & 4 & 3 & 10 & $83 \%$ \\
\hline 32. & Enggar Dieky & 3 & 3 & 4 & 4 & 11 & $91 \%$ \\
\hline 33. & Nurlaili Qolly & 3 & 4 & 4 & 3 & 11 & $91 \%$ \\
\hline 34. & Retno Dyah & 3 & 3 & 3 & 3 & 9 & $75 \%$ \\
\hline 35. & Yudhistira W. & 3 & 2 & 2 & 3 & 7 & $58 \%$ \\
\hline 36. & Evia Okta & 3 & 3 & 3 & 3 & 9 & $75 \%$ \\
\hline 37. & Handika. & 3 & 2 & 2 & 3 & 7 & $58 \%$ \\
\hline 38. & Indira. Priska & 3 & 3 & 3 & 2 & 8 & $66 \%$ \\
\hline 39. & Mega Rianita & 3 & 3 & 3 & 3 & 9 & $75 \%$ \\
\hline 40. & Raksiana & 3 & 3 & 3 & 2 & 8 & $66 \%$ \\
\hline 41. & Nichmatul Z & 3 & 3 & 3 & 3 & 9 & $75 \%$ \\
\hline 42. & Gita Nur A. & 3 & 2 & 2 & 2 & 6 & $50 \%$ \\
\hline \multicolumn{3}{|c|}{ Total sore } & 94 & 133 & 119 & 376 & \\
\hline \multicolumn{3}{|c|}{$\%)$} & $56 \%$ & $79 \%$ & $71 \%$ & $75 \%$ & \\
\hline
\end{tabular}

\section{Table 2}

The result of writing test of the cycle II

\begin{tabular}{|c|c|c|c|c|c|c|c|}
\hline \multirow[b]{2}{*}{ No } & \multirow[b]{2}{*}{ Name } & \multicolumn{4}{|c|}{ Score } & \multirow[b]{2}{*}{$\begin{array}{l}\text { Total } \\
\text { score }\end{array}$} & \multirow[b]{2}{*}{$\%$} \\
\hline & & $\begin{array}{l}\text { Total of } \\
\text { paragraph }\end{array}$ & $\begin{array}{l}\text { Transition } \\
\text { Signal }\end{array}$ & $\begin{array}{l}\text { Logical } \\
\text { Order }\end{array}$ & $\begin{array}{l}\text { Paragraph } \\
\text { Structure }\end{array}$ & & \\
\hline 1. & Agus S. & 3 & 3 & 3 & 3 & 9 & $75 \%$ \\
\hline 2. & Ratna & 3 & 3 & 3 & 3 & 9 & $75 \%$ \\
\hline 3. & Ardho Orani & 3 & 4 & 4 & 4 & 10 & $83 \%$ \\
\hline 4. & Rizki Nur A. & 3 & 4 & 4 & 4 & 11 & $91 \%$ \\
\hline 5. & Sulis Setiyo & 3 & 4 & 4 & 4 & 11 & $91 \%$ \\
\hline 6. & Andini Erdian & 3 & 3 & 3 & 3 & 9 & $75 \%$ \\
\hline 7. & Ainin $S$ & 3 & 4 & 4 & 4 & 10 & $83 \%$ \\
\hline
\end{tabular}


JEASP

2. ST Journal of English for Academic and Specific Purposes

Volume 2 Number 1, June, 2019

\begin{tabular}{|c|c|c|c|c|c|c|c|}
\hline 8. & Denddy Purwo & 3 & 2 & 2 & 2 & 7 & $58 \%$ \\
\hline 9. & Dhimas Adi & 3 & 3 & 3 & 3 & 8 & $66 \%$ \\
\hline 10. & Frita Ferdina & 3 & 3 & 3 & 3 & 9 & $75 \%$ \\
\hline 11. & Desi Yunita & 3 & 3 & 3 & 3 & 8 & $66 \%$ \\
\hline 12. & Destanto & 3 & 4 & 4 & 4 & 9 & $75 \%$ \\
\hline 13. & Linda Yunita & 3 & 3 & 3 & 3 & 9 & $75 \%$ \\
\hline 14. & Septi Peria Sari & 3 & 2 & 2 & 2 & 8 & $66 \%$ \\
\hline 15. & Yuda Tri & 3 & 4 & 4 & 4 & 10 & $83 \%$ \\
\hline 16. & Alfa Rindarini & 3 & 3 & 3 & 3 & 8 & $66 \%$ \\
\hline 17. & Arinta Novia & 3 & 3 & 3 & 3 & 8 & $66 \%$ \\
\hline 18. & Denis Kholida & 3 & 3 & 3 & 3 & 9 & $75 \%$ \\
\hline 19. & Ersi Egi & 3 & 3 & 3 & 3 & 9 & $75 \%$ \\
\hline 20. & Fitriana April & 3 & 4 & 4 & 4 & 10 & $83 \%$ \\
\hline 21. & Ihsan W. & 3 & 4 & 4 & 4 & 11 & $91 \%$ \\
\hline 22. & Nugroho Eko & 3 & 4 & 4 & 4 & 11 & $91 \%$ \\
\hline 23. & Eko Sukma & 3 & 3 & 3 & 3 & 9 & $75 \%$ \\
\hline 24. & Umi Saadah & 3 & 4 & 4 & 4 & 10 & $83 \%$ \\
\hline 25. & Uvike Zuria & 3 & 2 & 2 & 2 & 7 & $58 \%$ \\
\hline 26. & Yoesiva A. & 3 & 3 & 3 & 3 & 8 & $66 \%$ \\
\hline 27. & Arif Fandi & 3 & 3 & 3 & 3 & 9 & $75 \%$ \\
\hline 28. & Imam Supono. & 3 & 3 & 3 & 3 & 8 & $66 \%$ \\
\hline 29. & Priyo Emran. & 3 & 3 & 3 & 3 & 9 & $75 \%$ \\
\hline 30. & Anisa Santana & 3 & 3 & 3 & 3 & 9 & $75 \%$ \\
\hline 31. & Bagus Nandar & 3 & 4 & 4 & 4 & 12 & $100 \%$ \\
\hline 32. & Enggar Dieky & 3 & 4 & 4 & 4 & 12 & $100 \%$ \\
\hline 33. & Nurlaili Qolly & 3 & 4 & 4 & 4 & 12 & $100 \%$ \\
\hline 34. & Retno Dyah & 3 & 4 & 3 & 3 & 10 & $83 \%$ \\
\hline
\end{tabular}


JEASP

Journal of English for Academic and Specific Purposes

Volume 2 Number 1, June, 2019

\begin{tabular}{|c|c|c|c|c|c|c|c|}
\hline 35. & Yudhistira W. & 3 & 3 & 2 & 2 & 7 & $58 \%$ \\
\hline 36. & Evia Okta & 3 & 4 & 3 & 4 & 11 & $91 \%$ \\
\hline 37. & Handika. & 3 & 3 & 2 & 3 & 8 & $66 \%$ \\
\hline 38. & Indira. Priska & 3 & 4 & 3 & 4 & 11 & $91 \%$ \\
\hline 39. & Mega Rianita & 3 & 4 & 3 & 4 & 11 & $91 \%$ \\
\hline 40. & Raksiana & 3 & 4 & 3 & 4 & 11 & $91 \%$ \\
\hline 41. & Nichmatul Z & 3 & 3 & 3 & 4 & 10 & $83 \%$ \\
\hline 42. & Gita Nur A. & 3 & 2 & 2 & 3 & 7 & $58 \%$ \\
\hline \multicolumn{3}{|c|}{ Total sore } & 140 & 133 & 140 & 413 & \\
\hline \multicolumn{3}{|c|}{$(\%)$} & $83 \%$ & $79 \%$ & $83 \%$ & $82 \%$ & \\
\hline
\end{tabular}

The result of the questionnaire

Based on the result of the questionnaire above, it can be concluded that the students are interested in finishing the writing assignment through discussion way. Nearly $76,20 \%$ from the total of students in the class enjoy doing it. 
JEASP

HST Journal of English for Academic and Specific Purposes

Volume 2 Number 1, June, 2019

The graphics showing the score o writing results of Pre-test and Post-test (cycle I, cycle II)

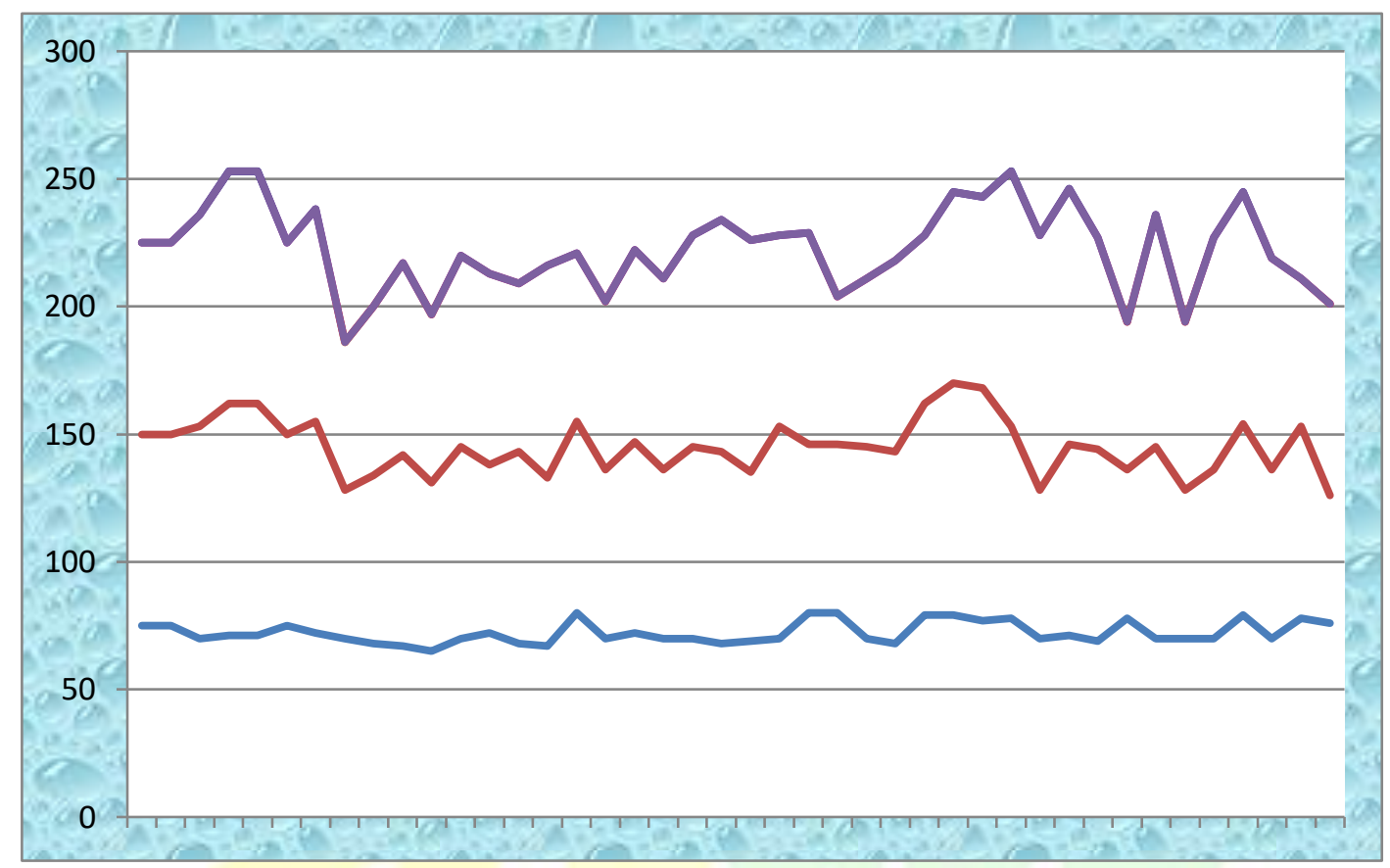

Note: blue ( the score of pre-test); brown ( the score of post-test I); violet (the score of post test II)

\section{DISCUSSION}

Some theories support how students can increase their achievement in learning English. One of them is writing a form, writing a composition through a discussion. Writing is much more than an orthographic of speech. It is most importantly, a purposeful selection and organization of experience. By experience, it means, facts, opinions, or ideas - whether acquired first hand (through direct perception and or actions or second hand (through reading or hearsay). This direct perception includes all kinds of writing from poem to the scientific experiment, for all have a purpose and an organized body of selected facts, opinions, or ideas. How clear the purpose, and how relevant and well organized the facts, determines the effectiveness of the writing. It is more than that; the composition requires knowledge of acceptable English rhetoric such as the use of transition signals. Transition signals are necessary to clarify the relation of ideas. The steps of a process are presented chronologically. The steps of a process are presented chronologically, and each requires much detail, we may introduce the word first, second, and third to keep the steps distinct. We may have to add less critical, just as important, more important to show that the ideas are being presented in the order of importance. The connectives specifically and generally show that we are preceding from the specific to general, least of all and most of all, from the 
JEASP

Journal of English for Academic and Specific Purposes

Volume 2 Number 1, June, 2019

least to the most frequent or command. The effectiveness of writing can be through as follows: the usage of transition signal and logical order (Nancy Arapoff, 1972: 200).

According to Donn Byrne (1970: 3), it is true that in writing, we have the necessary task of organizing our sentences carefully because we do not have the help of feedback from our readers. On the other hand, we do not usually have to write quickly: we can rewrite and revise our sentences until we are satisfied that we have expressed our meaning. A well-organized paragraph is one in which the sequence of sentences is logical and orderly. The other opinion states that organization of paragraph: the arranging of the sentences into the paragraph, the paragraph into the others by using transition signals and the application of a good paragraph structure. The more important thing is the writing activity done through discussion way like applied from the research.

\section{CONCLUSION}

Based on the previous discussion, the following conclusion can be drawn.

Writing a composition through three ways as follows: organization through transition Signal, organization through logical order and organization through the structure. This way can motivate the students in studying English, not boring to receive the writing material. The teacher must be creative to use a variation of writing teaching techniques, like the information above. The result of teaching variation, the students will be interested in listening to the teacher's information, they are also able to grasp the English material well; in this case, the writing material. Besides that, the students will be more creative to express the ideas in writing activity if they are often trained continuously with three ways related to research.

From the result of the research shows that the organization, through transition signal, organization through logical order and organization through a structure in writing a composition help the students to express their ideas in writing a composition. They will be easier to express their ideas in written form. Moreover, the writing activity is done in a group to make the students sharing each other (through a peer-to-peer discussion).

\section{REFERENCES}

Byrne, D. (1990). Writing Through some methods in teaching learning activities, Cambridge University Press. 
JEASP

Iaslo Journal of English for Academic and Specific Purposes

Volume 2 Number 1, June, 2019

Cowan, E. (1981). Writing through Discussion Way. Cambridge University Press.

Cowan, E. (1983). The Way of Teaching Writing. Ms Graw Hll International Book Company.

Framklin. V. (2002). Research Method on Language Learning. Cambridge University Press.

Fromklin, V. (2002). Writing Academic English. London: Addison-Wisley Publishing Company.

Levin, G. (1983). Short Essays, Model for Composition. New York: Harcout Brace Jowanovish, Inc.

Oshima, H. (1983). Writing with A Purpose. New York: Hoghton Mifflin Company.

Ozick, C. (1986). Teaching Writing. New York: Mc Graw Hill International Book Company.

Richard \& Rodger. (1999). Teaching writing based on a discussion way. International Journal of HSS.

Rodman, Robert \& Fromkin, V. (1983). An Introduction to Language. Japan: CNS College, Publishing, Holt, Richard and Winston.

Zamel. (1987). How to write a good paragraph. Cambridge University Press.

Zamel. (1987). Writing Task, An Authentic-Task Approach to Individual Writing Needs. Britain: Cambridge University Press. 